\title{
Why I Write So Many Books About Race
}

NAOMI ZACK

University of Oregon, Oregon, USA (nzack@uoregon.edu)

I relate how my life has intersected with my work in philosophy, both before and after a twenty-year absence from academia. Motivations for engaging in Philosophy of Race may be different from other projects because the subject itself is urgent and the philosopher may be a person of color. I describe the development of my own writing in this subfield, from ontological issues in the philosophy of science to moral issues in political philosophy and cultural criticism. The first addressed the biological reality of human racial taxonomy and the second has been about the inadequacy of treatments of race in the history of philosophy and injustice in contemporary social constructions of race.

Keywords: Race, mixed race, ethics and equality, philosophy of science and race, philosophical motivations

This is intended to be a "personal essay" about my work as a nonwhite philosopher. I find the premise condescending and somewhat annoying. I would not encourage anyone else who shares my demographics to follow my example, much less emulate me, so the personal example exercise is not a medium for pride. But, I do recognize the need for nonwhite and nonmale academic philosophers to "tell their stories." Unless they do, the small numbers of nonwhites in our profession and the disproportionately low percentage of nonmales will not change. Even with such stories it might not change, but I would hate to be responsible for even a tiny part of such ongoing exclusivity. The problem is not with either the maleness or whiteness of traditional philosophers, but with their general unexamined attitudes toward, and indifference about, the problems of women and nonwhite people in the world, as well as the academy. So I feel compensated that a task which annoys me insofar as I am making a spectacle of myself might be even more annoying to some of the spectators.

It seems appropriate to round out these splenetic introductory remarks with a reference to Friedrich Nietzsche. In Ecce Homo: How One Becomes What One Is, there is an essay entitled, "Why I Write Such Good Books." Nietzsche was a great writer and false modesty was not one of his vices. He did write good books, but the title of that essay expresses more than his pride or vanity. He easily assumed that those who do not, or do not think that they do, write good books would recognize the defiance in his lack of false modesty. More fundamentally, he assumed that good books are the kind of books one ought to be proud of writing. That implied act of valuation has been a privilege of those with advantaged social identities, who can afford (economically, psychologically, or socially) to become preoccupied with the quality of their work. That is a privilege because it allows the written work to stand on its own, quite apart from reality, much like art works under glass in a museum. Books in philosophy of race, by contrast, are rarely undertaken for the promise of their quality, but rather for their truth, usefulness, and potential to inspire social change. So the question for me is not why I write such good books- - of course I hope they are good but I don't care if they are not, so long as they become part of the collective record in college libraries-but why I write so many books, especially so many books about race. Five single-authored books, four edited anthologies, two text books, about 50 articles and chapters in other people's books and at least as many lectures and presentations, throughout the United States, and sometimes abroad: all since 1992. I have also written books and articles about $17^{\text {th }}$ century

Journal of World Philosophies 1 (Winter 2016): 131-137 
philosophy, feminism, and disaster, but most of my work has been about race. ${ }^{1}$ Part of the reason for the quantity is that I am very lucky not to have 'writers block,'2 and part is that it has seemed to me that the books I've written about race needed to be written.

My motivational urgency is shared by a cohort of philosophers of race, who are focused on what their work is about and approach their subjects with an agenda to change reality for the better. That is because the subject of race is inherently problematic as a site of confusion and injustice that has not yet received full-blown intellectual or ethical attention. Nonwhite people are aware of the confusion and moral wrongs attending race and race relations, but many otherwise benign members of the academic mainstream and U.S. media continue to regard nonwhite race apart from science and morality, as a curiosity or an exceptional kind of disadvantage that generates poverty, crime, sin, and stupidity. (The malign members of the intelligentsia and other subgroups hold nonwhite race in contempt or simply hate nonwhite people.) The subject of race is not yet taken seriously as a vitally important universal human problem. This is why those philosophers who write intensely, rigorously, passionately, and voluminously about race tend to be nonwhite people - they know that their scholarly discourse applies to them and their nearest and dearest, in real life.

So now we get to the personal part of this personal essay, assuming that the reader will in fact condescend to indulge it. ${ }^{3}$ (My earlier posit of condescension could be like preparing for a party to which no one comes.) I was born in Brooklyn, New York in 1944 and raised by my mother. She was an artist and the youngest child of Russian-Jewish immigrants. My father was black and Native-American. His father (my paternal grandfather) had been born a slave in Virginia and was six years old at the end of the Civil War. My parents were not married and neither did they ever live together. My mother and I lived mostly in Manhattan, on the lower East Side and Greenwich Village. She was not an observant Jew and we did not have contact with members of the black community.

My mother initially made up a story about my paternity and passed me off as Jewish. During my childhood and until sometime in the 1970s, American Jews were not considered racially white-they were Semites, or "Semitic" (a label that persists in "anti-Semitism," as a term referring to racial insult and injury against Jews). New York City, then, as now, was a mosaic of all races and nationalities. A Northern European appearance was not a dominant norm in the way I later learned it was in other parts of the United States. Illegitimacy, poverty, and my mother's lifelong lameness from childhood polio were at first sufficient to impart a generalized feeling of shame about myself, without raw self-consciousness about an ambiguous racial appearance. That inner writhing came later, after my mother confirmed my black ancestry when I was sixteen. I had tannish skin and wavy hair. My hips were more narrow than my shoulders. My lower jaw (mandibular structure) jutted out at a sharper angle than that of most white people. On the streets of New York, I was often taken for Puerto Rican, or "Spanish" as it was called then. (The disorientation caused by that misidentification prompted me to choose French instead of Spanish as a foreign language in high school, a choice I regret to this day.)

I thought about race a great deal during my late teens, but it was a secret pre-occupation, not discussed except for anguished moments of personal disclosure to very close friends. In a high school biology course, we studied Mendelian heredity. Gregor Mendel's work has been in and out of favor since his nineteenth century discovery of principles of heredity, but at least these generalizations have endured: The inherited physical traits of plants and animals, including human beings, are in large part the result of genetic material that is combined from both parents. And, the hereditary material from each parent does not all get inherited together but is dispersed and recombined at conception to make up the $50 \%$ genetic contribution to the offspring from each parent. In thinking about race, I reasoned (to myself) that the traits people considered signs of being a Negro

Journal of World Philosophies 1 (Winter 2016): 131-137 
were biologically no different from any other physical traits. I speculated that there probably was no one racial trait that a person inherited, which determined what race she was. I speculated.

During the same time period, in my senior year, I had an assignment to go to the New York Public Library and read and summarize parts of a book called Nichomachean Ethics by Aristotle. I was not consciousness of what I was reading, as such, but I dutifully took notes and then talked to the class in an oral report from those notes. This was for an English class and Mr. Glazer (or Glaser), my teacher, was himself taking a course at night on the same subject, although I did not know the name of the subject. Mr. Glazer was impressed by my report and asked if he could have my notes for his own course. This did not make sense to me, because I had stumbled through the reading and made notes without fully understanding what I was reading or writing, or later on, saying to my classmates, except maybe for some remarks about a "mean."

Nevertheless, it was beginning to dawn on me that I might be intelligent. I had good grades and did well on the college admissions aptitude tests of the time. I was admitted to New York University, UCLA, and the University of Australia. I was afraid to leave New York and went to NYU on a New York State Regents Scholarship, which was renewed each year, because I also got good grades in college. This was a time in higher education when women, Jews and other nontraditionals, including people of color, were admitted based on "merit" and neither Affirmative Action or initiatives for Diversity existed. Race was still not something that I, or anyone I knew, talked about, although I am sure there were millions of conversations going on beyond my narrow and comparatively sheltered mouse trap.

But how did I come to major in philosophy? My mother had dreamed I would be a medical doctor all through my childhood, but I convinced her to compromise with a plan to become a psychiatrist. But psychiatry required an M.D. and a pre-med major. Peer reports of the long hours demanded by organic chemistry repelled me. So by my freshman year, my ambitions were to become a psychologist. However, I never fully entirely embraced that goal because, in psychology, my interests were more in human subjectivities and I was on the 'experimental' track of the major. I was also developing a fondness for abstract thought, although I would not have been able to call it that, at the time. By my junior year, I noticed that most experiments in psychology were inconclusive and that compared to my philosophy professors, those who taught psychology were defensive when questions were asked that went to assumptions of their theoretical 'schools.'

In philosophy at NYU from 1962-1966, when I attended, William Barret taught existentialism and Milton K Munitz taught American Philosophy and analytic philosophy. Paul Edwards, who was later to edit MacMillan's eight-volume Encyclopedia of Philosophy, taught the history of philosophy, especially David Hume; I had the privilege of making him so angry in a class that he turned red and asked me to leave. All of these crusty codgers, and others, were intellectually inspiring in distinct ways. Over the summer before my senior year, I read a number of books to prepare for a major in philosophy, including Bertrand Russell's History of Westerm Philosophy. I graduated Summa Cum Laude with a double major in Psychology and Philosophy and was admitted to Phi Beta Kappa. I did not attend my graduation because it would have been an impersonal mass event. NYU was still immersed in its tradition as a teaching school, with a large commuter student body.

I was admitted to Columbia University with a First Year Woodrow Wilson College Teaching Fellowship. There were three women in the Philosophy $\mathrm{PhD}$ program while I was there and no female professors, although Mary Mothersill taught at Barnard College, which was in those days a women's school. Race was not even on the radar. I studied with Sidney Morgenbesser, Ernest Nagel, Robert Paul Wolff, Charles Parsons, Arthur Danto, Robert Cummings, and James Walsh who was Department Chair. Bernard Berofsky had also rejoined the faculty after a fabled absence of two years. We had a first year reading exam based on John Locke's Essay Concerning Human Understanding. We read a lot by John Dewey (unavoidable given his output) and there was a strong focus on Philosophy of Science. Jean-Paul Sartre and Martin Heidegger were shadowy

Journal of World Philosophies 1 (Winter 2016): 131-137 
presences, away from the main curriculum. There was a basically incomprehensible seminar on Hegel and access to a law school doctoral seminar taught by Wolfgang Friedman. (He was later killed by muggers in 1972.4) Quine taught for a term. The work was at times difficult, but I could do it. I became aware of my professors' neurotic foibles. Their wives served tea and cookies every afternoon in the lounge of Philosophy Hall (to this day guarded outside by an authentic cast of Rodin's “The Thinker.”)

When it came time to write my dissertation, I confidently thought I could develop an update on David Hume's constant conjunction theory of causation, involving the concept of atomic events, or events that could not be further divided in a given context. My committee became unstable and I was told that although my work looked good, the Department did not want to risk supporting something that original, unless I committed to a prolonged course of research that would take about twelve years. In those days, the average $\mathrm{PhD}$ was thirtyfive but at the age of 23-24, I could not see that far ahead. I ended up writing a dissertation on the epistemology of C.I. Lewis, an obscure American pragmatist who had been the most famous philosopher of his generation in the 1940's and 50's, but had drastically fallen out of favor by the late 1960s, where he remains to this day. ${ }^{5}$ This topic was pitched to me by Sidney Morgenbesser as something the Department would be pleased to see. I wrote it in four months, ${ }^{6}$ collected my degree, declined an opportunity to teach at Barnard College (Columbia took care of its own) where Mary Mothersill would have been my supervisor, and left academia and philosophy. I thought I could write a novel and extend some luck I'd had in the stock market.

I was away for twenty years. I lived kaleidoscopically, marrying and divorcing multiple times, free-lance writing, investing on my own in the stock market, and independently producing film and video. I lived in London, Los Angeles, St. Louis, and upstate New York. In terms of worldly success, nothing worked, except for my two grown sons of whom I am justifiably proud. By my mid-forties, I was on my own and in need of a stable job, with health care and pension benefits. I had learned how hard it is to succeed in the world on the strength of a $\mathrm{PhD}$ in philosophy and good ideas. I was willing and able to crawl back to academia in 1990. I began by teaching as an adjunct at SUNY, Albany (now the University at Albany), Rensselaer Polytechnic Institute, and the Distance Learning Center of Empire State College.

The academy had changed mightily since 1970! It was now not only possible, but ambivalently welcome, to write about feminism, race, existentialism-whatever one wanted. I began writing about race, starting from my own experience. My first article was "An Autobiographical View of Mixed-Race and Deracination," in the American Philosophical Association Newsletter on Philosophy and the Black Experience, which Leonard Harris at that time edited. A couple of months later, my return to studying Locke emerged as "Locke's Identity Meaning of Ownership," in the 1992 Locke Newsletter. In Spring 1991, I was offered a tenure-related job as Assistant Professor of Philosophy, through SUNY, Albany's "Target of Opportunity" Affirmative Action program. I made it clear that I was not a traditional black candidate for Affirmative Action. Personally, I felt obligated to "give back" for this ironic good fortune that had converted a problematic and agonizing personal identity into the means for a much-needed livelihood. I decided to specialize on race. I knew myself to be something of a dilatant and I knew that it had taken me twenty years, not only to chase down the vain follies and passions of youth, but to come to terms with the fact that I had written a "discussion of the literature" for my doctoral dissertation, instead of the work I wanted to do. It was not a question of content, but of form. I needed to choose a specialization that was my choice. It was a good decision. I have stuck with it this time. My experience as a philosopher of race has enabled me in Nietzsche's sense, to "become who I am" (sort of).

My first book, Race and Mixed Race, expanded on the APA Newsletter article. The monograph examined both the biological and social ideas of black and white racial identity. I demonstrated the idiocy of the "one drop rule" and challenged the historical and contemporary assumption that anyone with any black ancestry was all black. This led to a series of invited talks and chapters in other people's books. I edited an anthology, American

Journal of World Philosophies 1 (Winter 2016): 131-137

Copyright (C) 2016 Naomi Zack.

e-ISSN: 2474-1795 • http://scholarworks.iu.edu/iupjournals/index.php/jwp • doi: 10.2979/jourworlphil.1.1.09 
Mixed Race: The Culture of Micro-Diversity. Resulting controversies spurred me to write a second monograph on race, Philosophy of Science and Race. In that work, I examined all plausible foundations for scientific racial divisions in human biology, population genetics, and anthropology. The conclusion is that there is no scientific foundation for our ordinary or common sense idea that the existence of human races is a biological fact. There are, of course, differences among human ancestral groups, but there are also greater differences within any one group of exactly those traits considered "racial" in society. To the extent that ordinary ideas about race assume that there is a scientific foundation for human races, those ideas are false. None of this is to say that race is not real in society, or individual psychology, or shared beliefs and values. It is not to deny the existence of racism, especially anti-black racism. It is to say that race, meaning human races, is not real in biology. This perspective, which is the perspective of relevant scientists who have studied racial differences since the second half of the twentieth century, has succeeded in getting me labeled as a racial eliminativist.

I am not a racial eliminativist! (-Although to say that at this point is probably like Richard Nixon saying, "I am not a crook.") Racial eliminativism is the position that because there is no scientific biological foundation for human racial divisions, race should be eliminated. It has never been clear to me what this could mean. If people continue to believe that race has a scientific foundation when it doesn't, then they should correct their beliefs if science is their source of truth about human biology. Correcting a belief, as in the realization at a certain point in childhood that Santa Claus and the Easter Bunny do not exist, is hardly a process of eliminating Santa Claus or the Easter Bunny. It is impossible to eliminate something that does not exist. However, the 'anti-eliminativists' or 'retentionists' usually mean by 'race,' not just something biological, but social or cultural aspects of race.

Social or cultural race is not the kind of thing that can be eliminated, because it is a matter of thought, speech, writing, art, and the habits, practices, and policies related to racial oppression. Freedom of thought and speech and in writing and art are basic human rights that individuals, groups, and governments are now obligated to protect, morally, if not legally. No one knows how to eliminate oppressive practice, which applies to racism in people's hearts and minds, discrimination, and intergenerational institutional racism. 'Ought' implies 'can.' For all practical purposes social or cultural race cannot be eliminated. Overall, the anti-eliminativist or retentionist is arguing against a straw man. (I am not a straw man.)

The subject of race, or more accurately, divisions of human beings into races, as a biological reality, or not, is an issue of philosophy of science and ontology. There are other aspects of what we know as race than the putatively biological and I think it is these other aspects of race, which include history, oppression, and normative aspirations, which constitute our involvement with race on a daily basis, as embodied, social, economic, political, sexual, and emotional beings. Philosophically, ideas about race in these social and culturally contextualized ways are deeply connected with ideas about human equality, justice, and ethics or what we should do about inequality and injustice. Ethics, human equality, and justice have been the key themes in three recent books I've written about race: The Ethics and Mores of Race: Equality After the History of Philosophy; White Privilege and Black Rights: The Injustice of U.S. Police Racial Profiling and Homicide; Applicative Justice: A Pragmatic Empirical Approach to Racial Injustice.

In Ethics and Mores, I showed how the history of western political philosophy has no tradition that posits universal human equality. All of the noble humanistic rhetoric, from Plato to Rawls, presupposes a subject from a small group of privileged people in society. I reasoned that the idea of racial equality requires a foundational idea of human equality. I no longer think that is the case, because there is no plausible factual foundation from which to claim universal human equality (that pesky 'ought' implies 'can,' again). In Applicative Justice, I analyze what is called racial inequality as a failure to apply to nonwhites principles of justice that are applied to whites. In between these two books, I quickly wrote White Privilege and Black Rights as a response to

Journal of World Philosophies 1 (Winter 2016): 131-137

Copyright (C) 2016 Naomi Zack.

e-ISSN: 2474-1795 • http://scholarworks.iu.edu/iupjournals/index.php/jwp • doi: 10.2979/jourworlphil.1.1.09 
the recent high profile police shootings of unarmed young black men, and the persistent failure of grand juries to indict them or juries to convict. The now-popular discourse of white privilege does not address the violations of black rights in these cases. And the widespread reaction to injustice supports a view that instead of perfecting ideal notions of justice, in the Rawlsian legacy, philosophers ought to be more directly concerned with injustice, which is what ordinary people really care about. The racial injustice of our time is heart-breakingly simple: Nonwhites, especially blacks, are treated in ways that whites are not treated.

Naomi Zack ( $\mathrm{PhD}$ in Philosophy from Columbia University) has been Professor of Philosophy at the University of Oregon since 2001. Zack's newest book is The Theory of Applicative Justice: An Empirical Pragmatic Approach to Correcting Racial Injustice (2016). Related recent books are: White Privilege and Black Rights: The Injustice of US Police Racial Profiling and Homicide (2015) and The Ethics and Mores of Race: Equality after the History of Philosophy (2011, 2015). Additional monographs include: Ethics for Disaster (2009, 2010), Inclusive Feminism: A Third Wave Theory of Women's Commonality (2005), the short textbook, Thinking About Race, 1998, 2006); Bachelors of Science: 17th Century Identity Then and Now (1996); Philosophy of Science and Race (2002); Race and Mixed Race (1993). In production is a 51-contributor Oxford Handbook of Philosopby and Race (2017).

Zack's recent interviews include: PhilosophyTalk.org, "White Privilege and Racial Justice," Feb. 14, 2016, http://philosophytalk.org/shows/white-privilege-and-racial-injustice; Critique of white privilege discourse on PRI, "To the Best of Our Knowledge," Oct. 17, 2015. http://www.ttbook.org/book/lets-stop-talking-aboutprivilege; and "What 'White Privilege' Really Means," Interview by George Yancy in New York Times, Opinionator, Stone.http://opinionator.blogs.nytimes.com/category/the-stone/ November 5, 2014.

Zack maintains the multimedia websites on homelessness http://homelessness.philosophy.uoregon.edu/ and Philosophical Installations, http://philinstall.uoregon.edu/

$1 \quad$ See author's bio in the Notes on Contributors.

2 Despite the absence of writer's block, writing is still an exacting craft. You have to get used to carrying a piece around and continually going back to it, printing it out and marking it up and printing it out and doing that twelve (12! I am not exaggerating) times before you have a first draft to show someone else-anyone else, including your closest colleagues. That is, you have to obsess over the piece of writing you are working on to have something professional to show anyone else. You have to live with the figures about length, with syntax, with whether a point has been clearly made or not, with your introductions, and scholarly apparatuses — not to mention overall coherence and interest to the reader. One is no longer a student, writing for others to get their approval and going on with one's life. One has become a writer, suffering on her own, because one has chosen to do that, ostensibly for the sake of the end result, but really for the process. It isn't particularly enjoyable.

3 Another version of the following account occurs in a slightly different context, from a slightly different perspective as an interview on work and biographical background, transcribed in Conversations with AfricanAmerican Philosophers, ed. George Yancy (Routledge, 1998). I have not consulted that earlier account in writing this. Memories of the past are notoriously unstable and 17 years is a long time, so I did not want what I say now to be unduly influenced by my perspective then. However, I am assuming that the facts are consistent across both accounts.

$4 \quad$ Gail Robinson, "Suspects in Murder Arrested by Police: Search Continues for Two Brothers Wanted for Slaying Law Professor," http://spectatorarchive.library.columbia.edu/cgi-bin/columbia? $\mathrm{a}=\mathrm{d} \& \mathrm{~d}=\mathrm{cs} 19720922-$ 01.2.5\&e=-------en-20--1--txt-txIN-----(last accessed on 14 April 2016). (Of course, the suspects were young black men.)

5 This is partly due to the intellectual parricide of Lewis's most famous student W. V. O. Quine and unavoidable fact that he was not a nice man. See my review of a recent intellectual biography on Lewis, 'Murray Murphey's work and C. I. Lewis's Epistemology: Problems with Realism and the Context of Logical Positivism,' Transactions of the Charles S. Pierce Society: A Quarterly Journal in American Philosophy 42, no. 1, (2006): 32-44.

Journal of World Philosophies 1 (Winter 2016): 131-137 
6 This quick dissertation turned out to be remarkably enduring. Over 45 years later, I find myself teaching courses on C. I. Lewis! (I also teach courses on Hume, but with not too much focus on his theory of causation, because students in my department find the subject somewhat 'technical' and arcane.) 